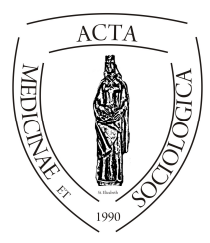

Acta Medicinae et

Sociologica (2020)

doi:

\title{
Health through the Eyes of the Romani minority
}

\author{
Kristýna Toumová $^{* 1}$, Valérie Tóthová ${ }^{2}$, Tereza Dušičková ${ }^{3}$, Jiří Kaas ${ }^{4}$, Jana \\ Maňhalová ${ }^{5}$ \\ ${ }^{1}$ University of South Bohemia in České Budějovice, Faculty of Health and Social Sciences, Institute of Nursing, \\ Midwifery and Urgent Care \\ ${ }^{2}$ University of South Bohemia in České Budějovice, Faculty of Health and Social Sciences, Institute of Nursing, \\ Midwifery and Urgent Care \\ ${ }^{3}$ University of South Bohemia in České Budějovice, Faculty of Health and Social Sciences, Institute of Nursing, \\ Midwifery and Urgent Care \\ ${ }^{4}$ University of South Bohemia in České Budějovice, Faculty of Health and Social Sciences, Institute of Nursing, \\ Midwifery and Urgent Care
}

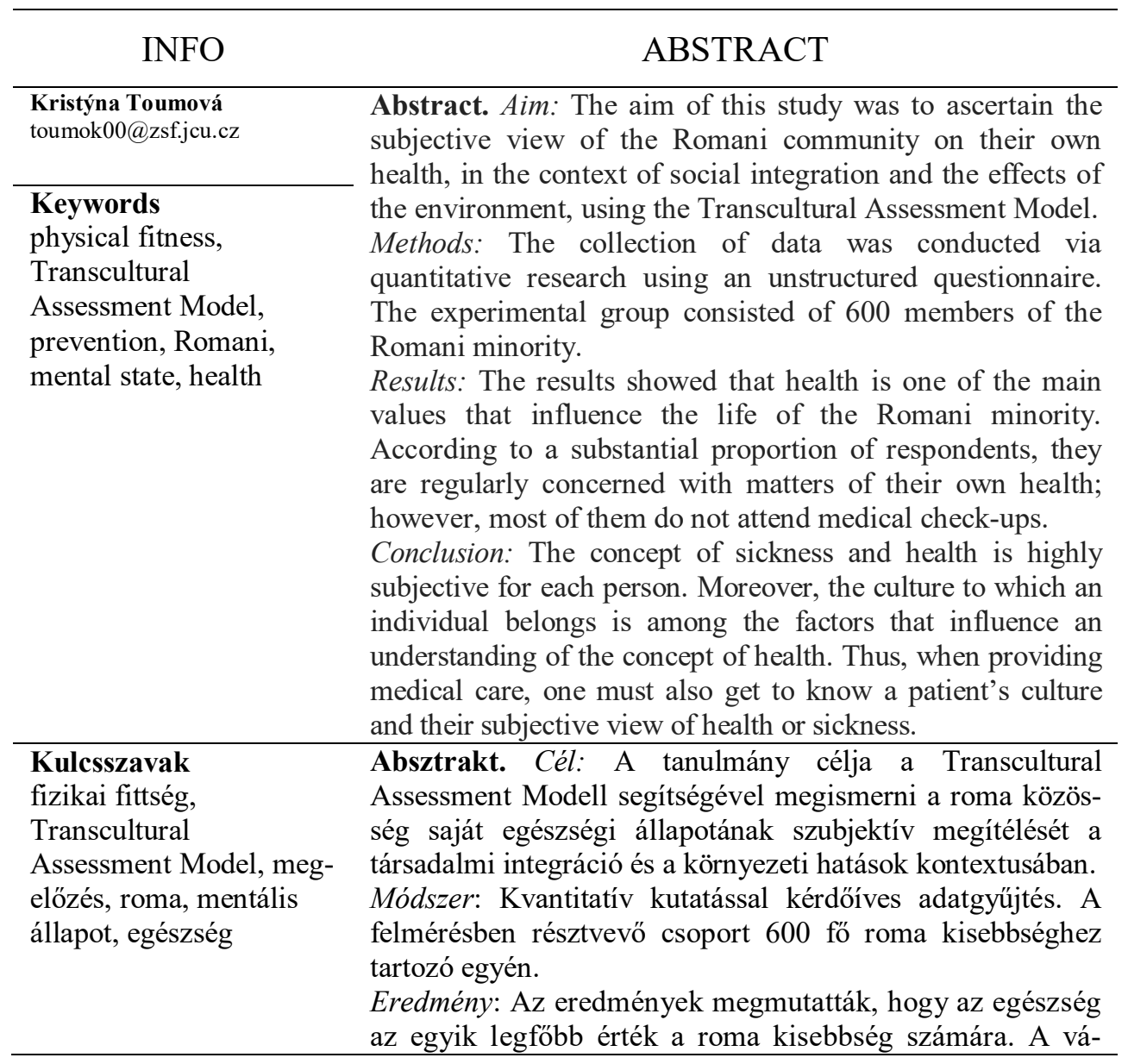




\begin{abstract}
laszadók jelentős hányada szerint gyakran aggódnak az egészségük miatt, ugyanakkor nem járnak egészségügyi vizsgálatokra.

Következtetés: Az egészség és betegség fogalma egyénenként jelentősen eltérő. Továbbá, az a kultúra, melyhez az egyén tartozik, azon a tényezőkhöz egyike, melyek befolyásolják az egészségről kialakított felfogásukat. Ennek következtében az egészségügyi ellátást nyújtónak tisztában kell lennie a beteg kultúrájával és azzal, hogy mi a felfogása az egészség-betegségről.
\end{abstract}

\author{
Abbreviations: \\ $\mathrm{p}=$ independence test \\ SASD $=$ Statistical Analysis of Social Data
}

\title{
Introduction
}

According to Maryšková (2010), Romani currently form one of the biggest ethnic minorities in Europe. The Romani population can be found across all European countries and therefore receives considerable attention. They are also the most numerous minority in the Czech Republic. According to the latest sources, 245.800 Romani live in the Czech Republic, making up 2.3\% of its population (Office of the Government of the Czech Republic, 2017). This section of the population often undergoes all kinds of research focusing on health and social matters. The reasons for conducting such research are the poor health of Romani people and the ongoing problems related to their social integration.

Having almost no representation in the public sphere, Romani are a typical minority (McGarry, 2014). According to Olišarová (2012), in many opinion polls the Romani people are placed in the worst positions. This is a fact which points to the majority's negative perception of them. Davidová (2010) states that problems arising from the position of the Romani vis-à-vis the wider society, make it essential to know this community closely. According to Maryšková (2010), the social position of the Romani people is a product of their lifestyle and the way of life bequeathed to them, which affect their integration into the mainstream of societies across the whole world. Considering the size of this minority, the problems of the Romani people need to be heard from the other side, i.e. from Romani individuals themselves. Their opinion can help us in establishing cooperation with members of the Romani community and providing them with appropriate health services. This is addressed by Tóthová (p. 11, 2012): "Nursing is a multidisciplinary field. It connects numerous different theories and findings from various domains of human knowledge towards a single goal: to provide an individualized nursing care." 


\section{Methodology}

Data was collected using quantitative method, namely a questionnaire, which was compiled using the Transcultural Assessment Model by J. N. Giger and R. E. Davidhizar. This model is suitable for obtaining comprehensive information from people of a different culture or religion.

In the first phase of data collection, pre-research was conducted in a form of an interview with 8 members of the Romani minority. The questions asked were in accordance with the above model aiming to check the respondents' understanding of the given questions. The questionnaire contained all the 6 cultural dimensions of the Transcultural Assessment Model in order to assess the individuals. These dimensions are Social Organization, Communication, Time, Space, Environmental Control and Biological Variations.

The research sample consisted of 600 Romani people. The sample was created by quota sampling and the criteria were age, sex, location and belonging to the Romani community. Overall, amongst the participants, there were 297 males (49\%) and 306 females (51\%) from 15 to $65+$, living in every region of the Czech Republic.

The research itself took place from February to December 2016. The questionnaire was distributed via organizations that unite the Romani community, and by using snowball sampling.

The collected data was processed by SASD software (Statistical Analysis of Social Data), where calculations of cumulative and relative frequency were performed with the calculation of mean values and measurement of statistical dispersion. In the second sorting, the Pearson's Chi-Square Goodness of Fit test and an independence test were used. Testing was conducted at the significance level $(\alpha=$ $0.05 ; 0.01 ; 0.001)$.

\section{Results}

In each area of the research regarding health, we focused on the acquired data and mapped the respondents' views on health, which reflect their subjective opinion, though.

Out of the 600 respondents, $44 \%$ stated that they were not undergoing any medical treatment right then. The most frequent medical conditions were hypertension $(23.8 \%)$ and diabetes mellitus $(22.8 \%)$ which were followed by mental illnesses $(10.3 \%)$, asthma $(10 \%)$, spinal and joint diseases $(8.8 \%)$ and myocardial infarction $(8.7 \%)$.

When analysing the connection between the gender of the respondents and the medical conditions they were being treated for, no statistical significance was found. Regarding the medical conditions, Romani males and females did not differ significantly. This means that Romani males and females suffer from similar illnesses at similar levels of severity (p 0.809).

The subjective point of view of respondents showed that the largest group perceived their physical condition as average (44.3\%). $24.7 \%$ perceived it as above 
average, $11.8 \%$ as well above average, while $13.8 \%$ perceived it as below average, and $4.8 \%$ as well below average.

Regarding their mental state, the results were similar to their physical fitness: $36.2 \%$ perceived it as average, $28.3 \%$ saw it as above average, $19.3 \%$ as well above average, while $11.2 \%$ evaluated it as below average and $4.5 \%$ as well below average.

A question about the factors that particularly affected the respondents' live yielded interesting results. They perceived health as a very important value $(12 \%)$, which follows the values of family (47\%) that has primary impact on their lives, and financial situation $(22.8 \%)$ (Table 1$)$.

\begin{tabular}{|l|l|l|}
\hline \multicolumn{3}{|l|}{ Values influencing respondents' lives sorted by importance } \\
\hline Values & Cumulative frequency & Relative frequency \\
\hline Family & 288 & $48.0 \%$ \\
\hline Financial situation & 137 & $22.8 \%$ \\
\hline Health & 72 & $12.0 \%$ \\
\hline Religion & 55 & $9.2 \%$ \\
\hline Community & 44 & $7.3 \%$ \\
\hline Other & 4 & $0.7 \%$ \\
\hline Total & $\mathbf{6 0 0}$ & $\mathbf{1 0 0 . 0} \%$ \\
\hline
\end{tabular}

Table 1. Values influencing respondents' lives sorted by importance

Health being among the most important values for the Romani minority is also supported by the answers to other questions. A part of the respondents expressed concern about their health. 7.5\% responded that they were constantly concerned, $40.7 \%$ was quite often concerned, $34 \%$ had an average concern, while $15.7 \%$ of them concerned only occasionally, and $1.8 \%$ responded that they never concerned about their health.

Regarding health, a statistically significant correlation was found between two variables: education and concern about health. As the level of an individual's education rises, so does his or her concern about their own health. The greatest concern for their health was shown by respondents with tertiary technical education or higher education $(\mathrm{p}<0.01)$.

The response to a question about whether respondents attend medical check-ups slightly contradicts these results. Only $45.5 \%$ of the Romani minority attends medical check-ups regularly, while $53.8 \%$ of the respondents do not do so. A possible explanation could be that people who are not undergoing any treatment express less concern about their health $(p<0.01)$. 


\section{Discussion}

Subjective evaluation of one's health is an important factor that actually influences a person's behaviour more than an objective view (Davidová, 2010). According to Nesvadbová (2010), several studies investigating the subjective opinions of Romani people about their own health showed that most of them viewed their health as very good, or at least good.

In our research, $44 \%$ of respondents stated that they were not undergoing any treatment. The rest generally had a chronic disease. The cause of these diseases can often be the occurrence of risk behaviour that is higher than in the majority population, which is supported by the 2016 data provided by the Czech Statistical Office. According to this data, 65\% of Romani adult females and 57\% of males smoke. The major problems are persistent smoking during pregnancy and smoking since early childhood which cause chronic diseases in the course of time. (Office of the Government of the Czech Republic, 2017). Furthermore, the proportion of Romani reporting on the occurrence of headaches, musculoskeletal disorders or mental illnesses is higher than that of the majority population (Office of the Government of the Czech Republic, 2017). Similar results are confirmed by the present research, in which the most frequent diseases of Romani were hypertension, diabetes mellitus, mental illnesses or spinal and joint diseases. In these cases the involvement of nurses and suitable motivation are important. Moreover, as Šedová (2015) states, considering the cultural differences in the population, cultural and linguistic competences need to be taken into account when maintaining health.

Although health represents an important part of Romani life, taking care of one's own health does not seem to be a primary concern (Nováková, 2012). Generally speaking, the physical fitness of the population is a considerable problem as far as prevention is concerned. According to Dolák (2015), medical check-ups form an important part of every human's health maintenance and play an important role in diagnosing disease. A 600-respondent study (with 302 and 298 respondents from the Romani and the majority population respectively) from 2015 entitled "Obesity and Being Overweight in the Romani Minority in the South Bohemian Region"showed that $65.5 \%$ of Romani respondents attended medical check-ups regularly compared to $77.2 \%$ of the majority population (Dolák, 2015). In the present research, with 600 Romani respondents, the results were somewhat worse: $45.5 \%$ of respondents attend medical check-ups regularly and $53.8 \%$ do not attend. Despite these results, $80 \%$ were of the subjective opinion that they were actively concerned about their health.

According to Maryšková (2010), prevention is not a priority among Romani, consequently, they care about their own health only when their disease progresses. Also there is a problem after the symptoms of a disease disappear because many simply stop abiding by precautions and following suggestions.

The subjective perception of one's health in the Romani population was the subject of research by Davidová et al. in 2007 and 2008. Most of the respondents in these studies stated that they felt average (i.e. neither good nor bad). However, according to the results it did not matter whether respondents belonging to the oldest generation felt subjectively worse than respondents of the younger generation. 
Subjective feeling is mainly affected by one's physical condition. Results generally showed that not only a particular disease affects the subjective perception of one's health, but the social determinants of health also affect it (Davidová, et al., 2010). One finding was fairly logical, i.e. the more seriously an individual is ill, the more often he or she is concerned about health and the more often visit a doctor. This indicator is probably very similar in the majority population.

According to Tóthová et al. (2010), although the value of health can be similar for everyone, the perception of health differs considerably among cultures. Research conducted by Davidová et. al. (2010) found that although most Romani respondents viewed health as one of the most important values, they did not sufficiently value preventive health precautions in the context of maintaining good health. According to Čeledová and Čevela (2010), this can be explained by factors that affect health. These factors are socioeconomic conditions, working conditions, interpersonal relationships, health and social care systems, demographic factors and finally the individual's own culture. Also, according to Molnar (2010), all these factors are important and play a role in the overall health of the Roma minority.

\section{Conclusion}

According to Vachková (2011), the concept of sickness and health is perceived uniquely by each person. Individuals are born into a specific social environment and during their life they undergo a process of socialization and acculturation which affect their attitudes towards life's values.

Whatever the case, it is essential to keep in mind one fundamental truth. Every person, whether a member of the Romani minority or the majority society, is a human being that has specific needs and different views of life, health and sickness. That is why everyone needs to be approached in an individual way, without unnecessary prejudices.

In the case of the Romani population it is particularly important to consider the individual's whole life within the Romani community and the great influence this community has had on that individual. Although this minority is integrated into the majority in many aspects of life, they still retain many traditional customs and ways of life. All these aspects need to be considered when communicating with a Romani patient. If we know the subjective perception of health, sickness or approach to life, we will be able to understand the person better and plan their treatment more effectively.

\section{Acknowledgments}

This contribution is a part of the grant research project number 048/2015/S, which is being conducted thanks to the financial support of the Grant Agency of the University of South Bohemia in České Budějovice. 


\section{References}

1. Čeledová L, Čevela R. (2010): Výchova ke zdraví. Vybrané kapitoly. Praha: Grada.

2. Davidová E, et al. (2010): Kvalita života a sociální determinanty zdraví u Romů v České a Slovenské republice. Praha: Triton.

3. Dolák F. (2015): Prevence jako součást moderního ošetřovatelství. In: Tóthová $\mathrm{V}$, et. al. Prevence obezity a nadváhy u romské minority v komunitním ošetřovatelství. České Budějovice: Lidové noviny.

4. Maryšková A. (2010): Specifika poskytování zdravotní péče romskému pacientovi. Sestra. 20(2): 25-27.

5. McGarry A. (2014): Roma as a political identity. Exploring representations of Roma in Europe. Ethnicities. 14(6): 756-774.

DOI: https://doi.org/10.1177/1468796814542182

6. Molnár A, et al (2010). Health impact asessment and evaluation of a Roma housing project in Hungary. Health \& Place. 16/2010:1240-1247. ISSN 13538292. DOI: https://doi.org/10.1016/j.healthplace.2010.08.011

7. Nesvadbová L, Elichová M. (2010): Zdraví a zdravotní stav Romů. In: Davidová E, et al. Kvalita života a sociální determinanty zdraví u Romů v České a Slovenské republice. České Budějovice: Zdravotně sociální fakulta.

8. Nováková D. (2012): Romská minorita. In: Tóthová V, et al. Kulturně kompetentní péče u vybraných minoritních skupin. Praha: Triton.

9. Olišarová V. (2012): Charakteristika romské minority. In: Tóthová V, et al. Prevence obezity a nadváhy u romské minority v komunitním ošetřovatelství. Praha: Nakladatelství lidové noviny.

10. Šedová L, et al. (2014): Romové a specifika zdravotní edukace. Studia Kinanthropologica. 15(3): 259-267.

11. Tóthová V, et al. (2010): Zabezpečení efektivní ošetřovatelské péče o vietnamskou a čínskou minoritu. Praha: Triton.

1. Tóthová V, et al. (2012): Kulturně kompetentní péče u vybraných minoritních skupin. Praha: Triton.

12. Office of the Government of the Czech Republic (2017): Report of the state of the Roma minority in the Czech Republic in 2016. Prague: Office of the Government Council of Roma Issues and the Secretariat of the Government Council of National Minorities.

13. Vachková E. (2011): Pacientovo pojetí nemoci v kontextu transkulturního ošetřovatelství. In: Mareš J, Vachková E. Pacientovo pojetí nemoci III. Brno: MSD. 